\title{
Properties of the zona pellucida of cytochalasin B-induced triploid mouse eggs
}

\author{
Anna Niemierko \\ Laboratory of Experimental Embryology and Department of Histology, Institute of Biostructure, \\ Medical School, Chatubińskiego 5, 02-004 Warsaw, Poland
}

\begin{abstract}
Summary. The hardening of the zona pellucida as a result of the cortical reaction was estimated in triploid oocytes produced with cytochalasin B by two different procedures. Triploid oocytes resulting from fertilization in the presence of cytochalasin B did not reveal hardening of the zona pellucida unlike triploids obtained by inhibiting in-vitro extrusion of the second polar body in oocytes fertilized in vivo.
\end{abstract}

\section{Introduction}

Release of the cortical granule contents initiates the changes in the properties of the zona pellucida known as the zona reaction. After the zona reaction, the zona pellucida becomes impenetrable to spermatozoa and resistant to the action of many physical and chemical agents and to digestion with proteolytic enzymes (see Gulyas \& Schmell, 1980).

Cytochalasin B affects microfilaments and fusion membranes (Godman \& Miranda, 1978). I have therefore examined the cortical reaction in cytochalasin B-induced triploid mouse oocytes.

\section{Materials and Methods}

Experiments were carried out on the eggs of Swiss albino mice fertilized by spermatozoa from $F_{1}$ $(\mathrm{CBA} / \mathrm{H} \times \mathrm{C} 57 \mathrm{BL})$ males. The zona reaction of the eggs was estimated by the time taken to digest the zona pellucida enzymically. The eggs were put into $0.1 \mathrm{ml}$ drops of $0.035 \%$ pronase (Sigma, St Louis, MO, U.S.A.) in phosphate-buffered saline ( $\mathrm{pH} \mathrm{7.2)} \mathrm{under} \mathrm{liquid} \mathrm{paraffin} \mathrm{at} 37^{\circ} \mathrm{C}$. Each group of eggs was observed under a dissecting microscope at 5 -min intervals and the number of eggs without a zona was counted. The low concentration of pronase leads to a longer time for lysis and so permits precise timing of zona digestion.

In Exp. 1 eggs were released from oviducts of spontaneously ovulating mice at 3 and $3.5 \mathrm{~h}$ after the vaginal plug was found and put in drops of medium with $5 \mu \mathrm{g}$ cytochalasin $\mathrm{B} / \mathrm{ml}$ under paraffin oil (Niemierko, 1975). After incubation for $7 \mathrm{~h}$ they were cleaned of follicular cells and segregated into triploids $(3 \mathrm{~N})$, diploids $(2 \mathrm{~N})$ and unfertilized, and placed in pronase solution. Control for the experiment comprised diploid eggs released from females 10 and $10.5 \mathrm{~h}$ after the vaginal plug was found.

In Exp. 2 eggs were fertilized in vitro in the presence of $5 \mu \mathrm{g}$ cytochalasin $\mathrm{B} / \mathrm{ml}$ (Niemierko \& Komar, 1976). After incubation for $7 \mathrm{~h}$ the eggs were segregated as in Exp. 1 and put into pronase solution. Control groups comprised diploid eggs resulting from fertilization without cytochalasin B and fertilization in the presence of $0.002 \%$ DMSO.

In Exp. 3 the time of zona dissolution was monitored and the percentage of hardening in eggs fertilized in vivo and in vitro was calculated. Pronase was applied to fertilized eggs at 1-h intervals

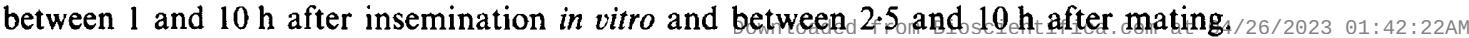


The percentage hardening of the zona $(\% \mathrm{H})$ was calculated as $(\mathrm{Tm}-\mathrm{Tu}) /(\mathrm{Tf}-\mathrm{Tu}) \times 100$, where $\mathrm{Tm}=$ mean time of zona lysis in fertilized eggs obtained at $10 \mathrm{~h} ; \mathrm{Tf}=$ mean time of zona lysis in fertilized eggs obtained every $1 \mathrm{~h}$ between 1 and $10 \mathrm{~h}$; and $\mathrm{Tu}=$ mean time of lysis of unfertilized eggs.

The results were statistically analysed by Student's $t$ test.

\section{Results}

The results of the zona lysis test are given in Table 1 . The time required for zona lysis of triploid and diploid eggs in Exp. 1 was similar to that of control diploid eggs.

Table 1. Times taken to lyse the zona pellucida of mouse eggs

\begin{tabular}{|c|c|c|c|c|}
\hline Exp. & Treatment & Ploidy of eggs & $\begin{array}{c}\text { No. of eggs } \\
\text { (no. of batches) }\end{array}$ & $\begin{array}{l}\text { Mean } \pm \text { s.e.m. } \\
\text { time of zona } \\
\text { lysis (min) }\end{array}$ \\
\hline \multirow[t]{2}{*}{1} & Cytochalasin B & $\begin{array}{l}3 \mathbf{N} \\
2 \mathrm{~N}\end{array}$ & $\begin{array}{l}87(6) \\
71(6)\end{array}$ & $\begin{array}{r}72 \cdot 5 \pm 1 \cdot 5 \\
73 \pm 1 \cdot 1\end{array}$ \\
\hline & None & $\begin{array}{l}\text { Unfertilized } \\
2 \mathrm{~N}\end{array}$ & $\begin{array}{r}139(6) \\
52(6)\end{array}$ & $\begin{array}{r}51 \pm 1 \cdot 7 \\
73 \cdot 1 \pm 1 \cdot 4\end{array}$ \\
\hline \multirow[t]{3}{*}{2} & Cytochalasin B & $\begin{array}{l}3 \mathrm{~N} \\
2 \mathrm{~N} \\
\text { Unfertilized }\end{array}$ & $\begin{array}{r}334(5) \\
72(5) \\
171(5)\end{array}$ & $\begin{array}{l}51.5 \pm 1 \cdot 3 \\
51.8 \pm 1 \cdot 7 \\
52.0 \pm 1.3\end{array}$ \\
\hline & DMSO & $\begin{array}{l}2 \mathrm{~N} \\
\text { Unfertilized }\end{array}$ & $\begin{array}{l}120(5) \\
192(5)\end{array}$ & $\begin{array}{l}73.0 \pm 1.7 \\
51.7 \pm 1.5\end{array}$ \\
\hline & None & $\begin{array}{l}2 \mathrm{~N} \\
\text { Unfertilized }\end{array}$ & $\begin{array}{l}112(5) \\
120(5)\end{array}$ & $\begin{array}{l}72.5 \pm 0.5 \\
52.5 \pm 1.2\end{array}$ \\
\hline
\end{tabular}

In the presence of cytochalasin B the zona did not harden and the time of zona lysis between fertilized eggs from Exp. 1 and eggs fertilized and unfertilized in the presence of cytochalasin B from Exp. 2 was significantly different $(P<0.001)$. DMSO had no effect on zona lysis time (Table 1).

The time sequence analysis of zona hardening in the eggs fertilized in vivo and in vitro is given in Table 2. In vivo, hardening of the zona was initiated about $2.5 \mathrm{~h}$ after mating, i.e. after the first

Table 2. Timing of hardening (see text) of zona pellucida in oocytes fertilized in vivo and in vitro

\begin{tabular}{|c|c|c|c|c|c|c|}
\hline \multirow[b]{2}{*}{$\begin{array}{l}\text { Time after } \\
\text { insemination } \\
\text { (h) }\end{array}$} & \multicolumn{3}{|c|}{ In vivo } & \multicolumn{3}{|c|}{ In vitro } \\
\hline & $\% \mathrm{H}$ & $\begin{array}{c}\% \\
\text { fertilized } \\
\text { eggs with } \\
\text { given } \\
\% \mathbf{H}\end{array}$ & $\begin{array}{l}\text { No. of } \\
\text { fertilized } \\
\text { eggs } \\
\text { assessed }\end{array}$ & $\% \mathbf{H}$ & $\begin{array}{c}\% \\
\text { fertilized } \\
\text { eggs with } \\
\text { given } \\
\% \mathbf{H}\end{array}$ & $\begin{array}{c}\text { No. of } \\
\text { fertilized } \\
\text { eggs } \\
\text { assessed }\end{array}$ \\
\hline 1 & - & - & - & 35 & 5 & 140 \\
\hline 2 & - & - & - & 35 & 70 & 150 \\
\hline 2.5 & 5 & 2.5 & 200 & - & - & - \\
\hline 3 & 25 & $81 \cdot 5$ & 152 & 50 & 86 & 93 \\
\hline 3.5 & 25 & 80 & 145 & - & - & - \\
\hline 4 & 50 & 80 & 150 & 100 & 83.8 & 105 \\
\hline 5 & 100 & 93 & 115 & 100 & 92 & 150 \\
\hline 7 & 100 & $93 \cdot 1$ & 76 & 100 & 99 & 81 \\
\hline 10 & 100 & 100 & 130 & 100 & 100 & 70 \\
\hline
\end{tabular}


spermatozoa have penetrated the oocytes. Between 3 and $3.5 \mathrm{~h}$ as many as $80 \%$ of eggs showed $25 \%$ hardening of the zona, indicating that at the time of transfer to the medium with cytochalasin B in Exp. 1 most oocytes had completed the cortical reaction. However, in-vitro-initiated zona hardening continued in the presence of cytochalasin $\mathrm{B}$ because the mean time of zona lysis in $3 \mathrm{~N}$ and $2 \mathrm{~N}$ eggs from Exp. 1 was not shorter than the time of $100 \%$ hardening of the zona in Exp. 3 .

The yield of fertilized eggs increased from 5 to $70 \%$ between 1 and $2 \mathrm{~h}$ after insemination in vitro, but only a few of the eggs indicated hardening of the zona by the first hour. Hardening of the zona in oocytes fertilized in vivo and in vitro developed similarly and $100 \%$ hardening of the zona occurred at 5 and $4 \mathrm{~h}$ respectively after fertilization.

\section{Discussion}

Cytochalasin B-induced triploid mouse oocytes obtained by two means differed in the properties of their zona pellucida. Triploids resulting from fertilization in the presence of cytochalasin B did not reveal hardening of the zona pellucida, although the zonae of eggs fertilized in vivo and then treated with cytochalasin B continued to harden. The temporal relationship between sperm entry and cortical granule release (Inoue \& Wolf, 1975; Nicosia, Wolf \& Inoue, 1977; Fukuda \& Chang, 1978; Sato, 1979) and the timing of hardening of the zona (present experiment) provide evidence that triploid eggs obtained by treating in-vivo fertilized eggs with cytochalasin $B$ undergo the cortical reaction and restructuring of microfilaments in the egg cortex before the cytochalasin can act.

It seems probable that cytochalasin B used to block cytokinesis of the second maturation division prevented fully or partly the extrusion of cortical granules when present during fertilization. Cytochalasin B causes corrugation of the oocyte surface (Johnson, Eager, MuggletonHarris \& Grave, 1975) which might prevent the approximation of cortical granules to the membrane and in this way interfere with fusion.

The action of cytochalasin B disrupts some elements of the cytoskeletal system (Godman \& Miranda, 1978) which are involved in the process of exocytosis of cortical granules (Szöllösi, 1967; Gulyas, 1980). Wassarman, Ukena, Josefowicz, Letourneau \& Karnovsky (1977) have shown that unfertilized mouse oocytes do not undergo a cortical reaction although pseudocleavage is induced by cytochalasin $\mathbf{B}$. It is also probable that oocytes fertilized in the presence of cytochalasin $\mathbf{B}$ undergo a partial cortical reaction as during premature granule release which does not affect egg penetrability (Nicosia et al., 1977) because there is too low a concentration of cortical enzymes to have a significant effect on the properties of the zona.

The hardening of the zona pellucida is a time-dependent process and does not differ in vivo or in vitro, being $2.5 \mathrm{~h}$ in vivo $(2.5-5 \mathrm{~h})$ and $3 \mathrm{~h}$ in vitro $(1-4 \mathrm{~h})$. In experiments with calcium ionophore A23187 (Schmell \& Gulyas, 1980) zona hardening occurred between 2 and $3 \mathrm{~h}$ after exposure to ionophore and at $3 \mathrm{~h}$ when exogenous peroxidase was added to inactivate eggs.

The ovoperoxidases from cortical granules modify the sperm receptor, a glycoprotein on the zona designated ZP3 (Bleil \& Wassarman, 1980) and also by cross-linking of tyrosine residues, modified glycoprotein ZP2, which provides hardening of the zona (Schmell \& Gulyas, 1980; Bleil, Beall \& Wassarman, 1981).

The present results and those of earlier work (Niemierko \& Komar, 1976) indicate that these functions are not expressed in the presence of cytochalasin $B$ and makes the supposition that cytochalasin $\mathbf{B}$ interferes with cortical granule extrusion more probable.

The research was partly supported by the Agricultural Academy (grant MR 11.10.1.A-2.) and Special Programme of Research Development and Research Training in Human Reproduction WHO. 


\section{References}

Bleil, J.D. \& Wassarman, P.M. (1980) Mammalian sperm-eggs interaction: identification of a glycoprotein in mouse egg zonae pellucidae possessing receptor activity for sperm. Cell 20, 873-882.

Bleil, J.D., Beall, C.F. \& Wassarman, P.M. (1981) Mammalian sperm-egg interaction: fertilization of mouse eggs triggers modification of the major zona pellucida glycoprotein, ZP 2. Devl Biol. 86, 189-197.

Fukuda, Y. \& Chang, M.C. (1978) The time of cortical granule breakdown and sperm penetration in mouse and hamster eggs inseminated in vitro. Biol. Reprod. 19, 261-266.

Godman, G.C. \& Miranda, A.F. (1978) Cellular contractility and visible effects of cytochalasin. In Cytochalasins-Biochemical and Cell Biological Aspects, ch. 12, pp. 277-429. Ed. S. W. Tanenbaum. North-Holland, Amsterdam.

Gulyas, B.J. (1980) Cortical granules of mammalian eggs. Int. Rev. Cytol. 63, 357-389.

Gulyas, B.J. \& Schmell, E.D. (1980) Ovoperoxidase activity in ionophore-treated mouse eggs. I. Electron microscopic localization. Gamete Res. 3, 267-277.

Inoue, M. \& Wolf, D.P. (1975) Fertilization-associated changes in the murine zona pellucida: a time sequence study. Biol. Reprod. 13, 546-551.

Johnson, M.H., Eager, D., Muggleton-Harris, A. \& Grave, H.M. (1975) Mosaicism in organisation of
Concanavalin A receptors on surface membrane of mouse egg. Nature, Lond. 257, 321-322.

Nicosia, S.V., Wolf, D.P. \& Inoue, M. (1977) Cortical granule distribution and cell surface characteristics in mouse eggs. Devl Biol. 57, 56-74.

Niemierko, A. (1975) Induction of triploidy in the mouse by cytochalasin B. J. Embryol. exp. Morph. 34, 279289.

Niemierko, A. \& Komar, A. (1976) Cytochalasin Binduced triploidy in mouse oocytes fertilized in vitro. J. Reprod. Fert. 48, 279-284.

Sato, K. (1979) Polyspermy-preventing mechanism in mouse eggs fertilized in vitro. J. exp. Zool. 210, 353359.

Schmell, E.D. \& Gulyas, B.J. (1980) Ovoperoxidase activity in ionophore treated mouse eggs. II. Evidence for the enzymes' role in hardening the zona pellucida. Gamete Res. 3, 279-290.

Szöllösi, D. (1967) Development of cortical granules and cortical reaction in rat and hamster. Anat. Rec. 159, 431-446.

Wassarman, P.M., Ukena, T.E., Josefowicz, W.J., Letourneau, G.E. \& Karnovsky, M.J. (1977) Cytochalasin B-induced pseudocleavage of mouse oocytes in vitro. Il. Studies of the mechanism and morphological consequences of pseudocleavage. J. Cell Sci. 26, 323337.

Received 13 February 1984 